\title{
Effects of chromosome substitutions on copper toxicity tolerance in wheat seedlings
}

\author{
G. GANEVA*,l, S. LANDJEVA* and M. MERAKCHIJSKA** \\ Institute of Genetics* and Institute of Plant Physiology**, \\ Bulgarian Academy of Sciences, BG-1113, Sofia, Bulgaria
}

\begin{abstract}
Substitution of wheat (Triticum aestivum L.) chromosomes 7A, 1D, 3A, 3B, 3D, 4A and 4D of cultivar Cappelle Desprez by their homologues of cultivar Bezostaya-1 increased the seedling tolerance to high concentrations of copper $\left(1 \mu \mathrm{M} \mathrm{CuSO}_{4} \cdot 5 \mathrm{H}_{2} \mathrm{O}\right.$ ). Substitution of chromosome $1 \mathrm{~A}$ had negative effects on seedling tolerance.

Additional key words: chromosome substitution lines, root growth, shoot growth.
\end{abstract}

Soil heavy metal contamination poses serious problems concerning crop productivity in affected lands. Copper $(\mathrm{Cu})$ is an essential micronutrient for plants, but can be toxic at excessive concentrations. Its phytotoxicity is manifested by considerable root growth inhibition (Fargašová 2001), induction of various damages of chromosomes, nuclei and cell membranes (Jiang et al. 2001), as well as numerous metabolic disturbances (Fernandez and Henriques 1991, Ouzounidou 1995). Accordingly, yield is significantly decreased under Cu stress (Moustakas et al. 1997), so emphasis is placed on developing tolerant genotypes. Breeding for tolerance requires knowledge on the effects of individual chromosomes on plant response to metal stress. In wheat, single chromosome substitution lines have been developed between several key cultivars and have been used to assay the effects of individual chromosomes on important agronomic characters (Law and Worland 1996, Ganeva et al. 2003). The aim of this work was to study the effects of chromosomes of wheat cultivar Bezostaya-1, substituted for the homologous chromosomes of cultivar Cappelle Desprez, on seedling tolerance to high $\mathrm{Cu}$ concentrations.

Wheat (Triticum aestivum L.) cultivars Cappelle Desprez and Bezostaya-1, and eighteen Cappelle Desprez/Bezostaya-1 chromosome substitution lines, kindly provided by Prof. C.N. Law, John Innes Centre, Norwich, UK, were used in the study. Seeds were germinated on moist filter paper in dark at $18{ }^{\circ} \mathrm{C}$ for $3 \mathrm{~d}$. Seedlings with roots approximately $2.5 \mathrm{~cm}$ long were placed on $1 \mu \mathrm{M} \mathrm{CuSO}_{4} .5 \mathrm{H}_{2} \mathrm{O}$ solution. According to our earlier studies on seedling response to increasing concentrations of $\mathrm{Cu}$ ions (Landjeva et al. 2003), this concentration allows the differentiation between genotypes. Plants grown on water were used as control. After $6 \mathrm{~d}$ treatments at $18^{\circ} \mathrm{C}$ root and shoots length and fresh biomass were measured on 30 plants per variant for each genotype. Tolerance index was calculated for the roots length, roots biomass, shoots length and shoots biomass according to Macnair (1993) as the ratio between roots or shoots length (biomass) in $\mathrm{Cu}$-stressed seedlings and roots or shoots length (biomass) in control plants. Student's $t$-test was applied to estimate the significance of differences in the tolerance index between substitution lines and cultivar Cappelle Desprez.

Exposure of seedlings to $\mathrm{Cu}$ inhibited mainly the growth of roots (Table 1), while the shoots growth was only slightly negatively influenced in Cappelle Desprez, or stimulated in Bezostaya-1 and some of the lines (Table 2). Roots length and biomass were reduced in the least extent in Bezostaya-1 and in the highest extent in Cappelle Desprez (Table 1). The performance of the substitution

Received 17 December 2002, accepted 10 September 2003.

Acknowledgements: The study was partially supported by the Bulgarian NSF, Contract No 1207/02. The technical assistance of Mrs. K. Prokopova and Mrs. S. Paunova is greatly appreciated.

'Author for correspondence; fax: (+359) 297855 16; e-mail: ganka ganeva(ayahoo.com 
lines was on average better than Cappelle Desprez, but did not reach the tolerance of Bezostaya-1.

Eleven of the substitution lines showed significant deviations from Cappelle Desprez (Tables 1, 2). Chromosomes 7A and ID of Bezostaya-1 had considerable positive effects on the four studied growth parameters. Chromosomes 3A, 3B, 3D, 4A, 4D affected positively mainly the roots growth, while chromosomes
5BL.7BL, $1 \mathrm{~B}$ and $6 \mathrm{D}$ influenced predominantly the growth of shoots. Chromosome lA was the only chromosome with reducing effects on seedling tolerance in comparison to Cappelle Desprez. In general, chromosomes 2A, 2B and 2D of Bezostaya-1 had negative effects on the seedling growth under $\mathrm{Cu}$ stress, but the deviations in the tolerance indeces from Cappelle Desprez were not statistically significant.

Table 1. Root length and fresh biomass (mean \pm S.E.) and tolerance index (TI) in wheat cultivars Cappelle Desprez (CD) and Bezostaya-1 (BEZ), and CD (BEZ) chromosome substitution lines after treatment of seedlings with $1 \mu \mathrm{M} \mathrm{CuSO}_{4} .5 \mathrm{H}_{2} \mathrm{O}(* * * * *$. differences from Cappelle Desprez, significant at $P=0.01$ and 0.001 , respectively).

\begin{tabular}{|c|c|c|c|c|c|c|}
\hline \multirow[t]{2}{*}{ Genotype } & \multicolumn{3}{|l|}{ Root length $[\mathrm{cm}]$} & \multicolumn{3}{|c|}{ Root biomass [mg] } \\
\hline & control & $\mathrm{Cu}$ & $\mathrm{TI}[\%]$ & control & $\mathrm{Cu}$ & $\mathrm{T}][\%]$ \\
\hline $\mathrm{CD}$ & $16.9 \pm 0.31$ & $9.2 \pm 0.35$ & 54.5 & $62.1 \pm 0.11$ & $43.4 \pm 0.08$ & 69.9 \\
\hline BEZ & $17.7 \pm 0.23$ & $12.6 \pm 0.33$ & $71.2^{* *}$ & $77.0 \pm 0.13$ & $57.0 \pm 0.12$ & 74.0 \\
\hline $\mathrm{CD}(\mathrm{BEZ} 1 \mathrm{~A})$ & $15.4 \pm 0.34$ & $7.0 \pm 0.28$ & 45.5 & $53.9 \pm 0.10$ & $27.5 \pm 0.06$ & $51.0^{* *}$ \\
\hline $\mathrm{CD}(\mathrm{BEZ}, 2 \mathrm{~A})$ & $17.9 \pm 0.29$ & $9.7 \pm 0.21$ & 54.4 & $101.0 \pm 0.10$ & $61.2 \pm 0.11$ & 60.6 \\
\hline $\mathrm{CD}(\mathrm{BEZ} .3 \mathrm{~A})$ & $15.6 \pm 0.28$ & $12.3 \pm 0.25$ & $78.9^{* * *}$ & $83.0 \pm 0.11$ & $68.5 \pm 0.09$ & $82.5^{* *}$ \\
\hline $\mathrm{CD}(\mathrm{BEZ} 4 \mathrm{~A})$ & $13.8 \pm 0.20$ & $10.5 \pm 0.33$ & $76.1 * * *$ & $71.6 \pm 0.05$ & $54.7 \pm 0.04$ & 76.4 \\
\hline $\mathrm{CD}(\mathrm{BEZ} 5 \mathrm{~A})$ & $15.4 \pm 0.23$ & $8.8 \pm 0.25$ & 57.1 & $78.2 \pm 0.08$ & $46.7 \pm 0.07$ & 59.7 \\
\hline $\mathrm{CD}(\mathrm{BEZ} 6 \mathrm{~A})$ & $15.8 \pm 0.32$ & $9.1 \pm 0.25$ & 57.6 & $76.0 \pm 0.10$ & $57.5 \pm 0.06$ & 75.7 \\
\hline $\mathrm{CD}(\mathrm{BEZ} 7 \mathrm{~A})$ & $18.9 \pm 0.34$ & $14.1 \pm 0.24$ & $74.6^{* * *}$ & $63.8 \pm 0.17$ & $74.0 \pm 0.11$ & $116.0^{* * *}$ \\
\hline $\mathrm{CD}(\mathrm{BEZ} 1 \mathrm{~B})$ & $16.7 \pm 0.28$ & $8.3 \pm 0.30$ & 49.7 & $76.0 \pm 0.11$ & $53.4 \pm 0.13$ & 70.3 \\
\hline $\mathrm{CD}(\mathrm{BEZ} 2 \mathrm{~B})$ & $14.3 \pm 0.20$ & $7.6 \pm 0.18$ & 53.1 & $69.0 \pm 0.10$ & $49.3 \pm 0.06$ & 71.4 \\
\hline $\mathrm{CD}(\mathrm{BEZ} 3 \mathrm{~B})$ & $17.4 \pm 0.22$ & $12.1 \pm 0.34$ & $69.5^{* *}$ & $70.1 \pm 0.12$ & $51.1 \pm 0.10$ & 72.9 \\
\hline $\mathrm{CD}(\mathrm{BEZ} 5 \mathrm{BL} .7 \mathrm{BL})$ & $17.7 \pm 0.35$ & $11.4 \pm 0.39$ & 64.4 & $64.4 \pm 0.17$ & $52.6 \pm 0.18$ & $81.7^{* *}$ \\
\hline $\mathrm{CD}(\mathrm{BEZ} 6 \mathrm{~B})$ & $14.0 \pm 0.17$ & $8.9 \pm 0.24$ & 63.6 & $73.0 \pm 0.10$ & $55.9 \pm 0.10$ & 76.6 \\
\hline CD (BEZ 1D) & $17.9 \pm 0.21$ & $13.1 \pm 0.29$ & $73.2 * * *$ & $81.1 \pm 0.13$ & $70.1 \pm 0.11$ & $86.4^{* * *}$ \\
\hline $\mathrm{CD}(\mathrm{BEZ} 2 \mathrm{D})$ & $17.2 \pm 0.24$ & $9.5 \pm 0.20$ & 55.2 & $84.5 \pm 0.10$ & $51.2 \pm 0.09$ & 60.6 \\
\hline $\mathrm{CD}(\mathrm{BEZ} 3 \mathrm{D})$ & $15.1 \pm 0.14$ & $11.4 \pm 0.30$ & $75.5^{* * *}$ & $69.9 \pm 0.10$ & $60.7 \pm 0.11$ & $86.8^{* * *}$ \\
\hline $\mathrm{CD}(\mathrm{BEZ} 4 \mathrm{D})$ & $18.1 \pm 0.24$ & $13.6 \pm 0.35$ & $75.1^{* * *}$ & $82.6 \pm 0.14$ & $71.5 \pm 0.16$ & $86.6^{* * *}$ \\
\hline $\mathrm{CD}(\mathrm{BEZ} 5 \mathrm{D})$ & $17.0 \pm 0.28$ & $10.7 \pm 0.26$ & 62.9 & $77.9 \pm 0.16$ & $48.8 \pm 0.08$ & 62.6 \\
\hline $\mathrm{CD}(\mathrm{BEZ}$ 6D) & $17.5 \pm 0.33$ & $10.9 \pm 0.33$ & 62.3 & $74.5 \pm 0.17$ & $53.0 \pm 0.11$ & 71.1 \\
\hline $\mathrm{CD}(\mathrm{BEZ})$ lines (mean) & & & $63.8 \pm 2.4$ & & & $74.9 \pm 3.4$ \\
\hline
\end{tabular}

Studies on genetics of metal toxicity tolerance in plants suggest a model of polygenic inheritance, including few major genes, governing the tolerance, and other genes with enhancing or modifying effects (Macnair 1993). Our study shows that genes for $\mathrm{Cu}$ tolerance in wheat seedlings are located on more than one chromosome, thus supporting the polygenic model of inheritance. The cultivars Cappelle Desprez and Bezostaya-1 carry different allelic types at these loci. The performance of the substitution lines suggests that the individual chromosomes affect the $\mathrm{Cu}$ tolerance with almost equal contribution. The degree of tolerance depends also on the genetic background and this can explain the intermediate performance of the substitution lines in comparison to Bezostaya- 1 and Cappelle Desprez. Our results indicated that chromosomes $7 \mathrm{~A}$ and 1D were most strongly associated with increased tolerance. The same chromosomes were shown to exert mainily negative effects on yield and yield components (Ganeva et al. 2003). Chromosomes 4A, 4D, 7A and $5 \mathrm{BL} .7 \mathrm{BL}$ of Bezostaya-1, associated with increased $\mathrm{Cu}$ tolerance, were shown to increase the frost resistance in wheat (Ganeva et al. 2003).

According to Manyowa and Miller (1991), all seven homoeologous groups of chromosomes in tribe Triticeae carry genes for metal toxicity tolerance. The group 3 of chromosomes was shown to carry tolerance genes for excess Al in wheat and rye (Manyowa and Miller 1991). and Aegilops uniaristata (Miller et al. 1992); for excess B in Secale cereale, Aegilops sharonensis and Agropyron elongatum (Manyowa and Miller 1991); for excess $\mathrm{Cu}$ in Aegilops geniculata (Landjeva et al. 1998). Wheat chromosomes $4 \mathrm{~A}$ and $4 \mathrm{D}$ were reported to carry genes for tolerance to excess $\mathrm{Al}, \mathrm{B}$ and $\mathrm{Cu}$ (Manyowa and Miller 1991). The homoeologous group 7 was shown to confer $\mathrm{Cu}$ toxicity tolerance in Triticum spelta and synthetic 
hexaploid wheat [Triticum dicoccum $\times$ Aegilops tauschii] (Manyowa and Miller 1991). The effects of chromosome 1D were new and merit further investigation. The obtained information about the effects of individual wheat chromosomes on copper stress response can be helpful for chromosome-mediated genetic manipulation in wheat, aiming to increase the crop productivity in mineral-toxic soils.

Table 2. Shoot length and fresh biomass (mean \pm S.E.) and tolerance index (TI) in wheat cultivars Cappelle Desprez (CD) and Bezostaya-1 (BEZ), and CD (BEZ) chromosome substitution lines after treatment of seedlings with $1 \mu \mathrm{M} \mathrm{CuSO}_{4} .5 \mathrm{H}_{2} \mathrm{O}\left({ }^{*},{ }^{* *}\right.$, *** differences from Cappelle Desprez, significant at $P=0.05,0.01$ and 0.001 , respectively).

\begin{tabular}{lrrrrrr}
\hline Genotype & \multicolumn{2}{l}{ Shoot length [cm] } & \multicolumn{2}{l}{ Shoot biomass [mg] } \\
& \multicolumn{1}{l}{ control } & \multicolumn{1}{l}{ Cu } & TI [\%] & control & Cu & TI [\%] \\
\hline CD & $13.5 \pm 0.37$ & $12.8 \pm 0.33$ & 94.8 & $72.1 \pm 0.03$ & $65.9 \pm 0.02$ & 91.4 \\
BEZ & $15.0 \pm 0.29$ & $15.9 \pm 0.34$ & 105.3 & $104.7 \pm 0.02$ & $113.4 \pm 0.02$ & 108.3 \\
CD (BEZ 1A) & $10.1 \pm 0.34$ & $9.4 \pm 0.28$ & 93.1 & $59.4 \pm 0.02$ & $50.9 \pm 0.02$ & 85.7 \\
CD (BEZ 2A) & $12.9 \pm 0.34$ & $13.1 \pm 0.23$ & 101.6 & $82.7 \pm 0.04$ & $85.3 \pm 0.03$ & 103.1 \\
CD (BEZ 3A) & $12.7 \pm 0.21$ & $13.2 \pm 0.20$ & 103.9 & $79.0 \pm 0.02$ & $77.0 \pm 0.02$ & 97.5 \\
CD (BEZ 4A) & $12.6 \pm 0.26$ & $12.3 \pm 0.25$ & 97.6 & $84.3 \pm 0.02$ & $78.2 \pm 0.02$ & 92.8 \\
CD (BEZ 5A) & $12.0 \pm 0.27$ & $12.1 \pm 0.30$ & 100.8 & $77.9 \pm 0.06$ & $70.8 \pm 0.13$ & 90.9 \\
CD (BEZ 6A) & $12.6 \pm 0.41$ & $11.2 \pm 0.33$ & 88.9 & $78.9 \pm 0.08$ & $78.4 \pm 0.03$ & 99.4 \\
CD (BEZ 7A) & $8.7 \pm 0.54$ & $11.3 \pm 0.47$ & $129.9 * * *$ & $54.4 \pm 0.10$ & $78.5 \pm 0.09$ & $144.3^{* * *}$ \\
CD (BEZ 1B) & $11.7 \pm 0.39$ & $11.6 \pm 0.28$ & $99.1 *$ & $70.0 \pm 0.11$ & $76.7 \pm 0.10$ & $109.6^{* *}$ \\
CD (BEZ 2B) & $12.2 \pm 0.24$ & $11.4 \pm 0.32$ & 93.4 & $72.9 \pm 0.06$ & $67.8 \pm 0.10$ & 93.0 \\
CD (BEZ 3B) & $14.0 \pm 0.28$ & $13.1 \pm 0.34$ & 93.6 & $90.7 \pm 0.05$ & $90.2 \pm 0.09$. & 99.4 \\
CD (BEZ 5BL.7BL) & $12.4 \pm 0.33$ & $13.2 \pm 0.34$ & $106.5^{* *}$ & $82.4 \pm 0.07$ & $89.0 \pm 0.07$ & $108.0^{* *}$ \\
CD (BEZ 6B) & $12.6 \pm 0.19$ & $11.4 \pm 0.35$ & 90.5 & $77.7 \pm 0.03$ & $77.9 \pm 0.11$ & 100.3 \\
CD (BEZ 1D) & $15.0 \pm 0.33$ & $15.5 \pm 0.21$ & $103.3 *$ & $86.9 \pm 0.10$ & $92.5 \pm 0.06$ & $106.4^{*}$ \\
CD (BEZ 2D) & $15.1 \pm 0.30$ & $13.5 \pm 0.28$ & 89.4 & $93.7 \pm 0.04$ & $82.3 \pm 0.02$ & 87.8 \\
CD (BEZ 3D) & $13.4 \pm 0.24$ & $13.5 \pm 0.26$ & 100.7 & $86.5 \pm 0.03$ & $93.2 \pm 0.07$ & $107.7^{* *}$ \\
CD (BEZ 4D) & $14.6 \pm 0.27$ & $14.8 \pm 0.29$ & 101.4 & $94.7 \pm 0.07$ & $97.4 \pm 0.06$ & 102.9 \\
CD (BEZ 5D) & $14.1 \pm 0.39$ & $13.3 \pm 0.35$ & 94.3 & $94.9 \pm 0.09$ & $87.7 \pm 0.08$ & 92.4 \\
CD (BEZ 6D) & $13.0 \pm 0.47$ & $13.8 \pm 0.33$ & $106.2^{* *}$ & $78.8 \pm 0.10$ & $82.2 \pm 0.04$ & $104.3^{*}$ \\
CD (BEZ) lines (mean) & & & & & & $101.4 \pm 3.0$ \\
\hline & & & $99.7 \pm 2.2$ & & &
\end{tabular}

\section{References}

Fargašová, A.: Phytotoxic effects of $\mathrm{Cd}, \mathrm{Zn}, \mathrm{Pb}, \mathrm{Cu}$ and $\mathrm{Fe}$ on Synapis alba L. seedlings and their accumulation in roots and shoots. - Biol. Plant. 44: 471-473, 2001.

Fernandez, J.C., Henriques, F.S.: Biochemical, physiological and structural effects of excess copper in plants. - Bot. Rev. 57: 246-273, 1991.

Ganeva, G., Landjeva, S., Bochev, B.: Study on wheat 'Cappelle Desprez'/'Bezostaya-1' intervarietal substitution lines under conditions of Bulgaria. - Genet. Breed. (Sofia) 32: 47-54, 2003.

Jiang, W., Liu, D., Liu, X.: Effect of copper on root growth, cell division and nucleolus of Zea mays. - Biol. Plant. 44: 105$109,2001$.

Landjeva, S., Merakchijska, M., Ganeva, G.: Seedling copper tolerance and cytogenetic characterization of wheatAegilops ovata hybrid lines. - Wheat Inform. Serv. 87: 2730,1998

Landjeva, S., Merakchijska-Nikolova, M., Ganeva, G.: Copper toxicity tolerance in Aegilops and Haynaldia seedlings. -
Biol. Plant. 46: 479-480, 2003.

Law, C.N., Worland, A.J.: Inter-varietal chromosome substitution lines in wheat - revisited. - Euphytica 89: 1-10, 1996.

Macnair, M.R.: The genetics of metal tolerance in vascular plants. - New Phytol. 124: 54 I-559, 1993.

Manyowa, N.M., Miller, T.E.: The genetics of tolerance to high mineral concentrations in the tribe Triticeae - a review and update. - Euphytica 57: 175-185, 1991.

Miller, T.E., Reader, S.M., King, I.P.: Alluminium Tolerant Wheat. - Annu. Rep. Plant Breed. Inst., Cambridge 1992.

Moustakas, M., Ouzounidou, G., Symeonidis, L., Karataglis, S.: Field study of the effects of excess copper on wheat photosynthesis and productivity. - Soil Sci. Plant Nutr. 43: 531-539, 1997.

Ouzounidou, G.: Cu-ions mediated changes in growth, chlorophyll and other ion contents in a Cu-tolerant Koeleria splendens. - Biol. Plant. 37: 71-78, 1995. 